\title{
DYNAMIC POTENTIAL OF FEEDBACK IN SELF- REGULATED LEARNING AND MOTIVATION OF CHILDREN WITH MATHEMATICAL LEARNING DIFFICULTIES
}

\author{
LINDA SALIHU ${ }^{1,2}$, MIKKO ARO $^{2}$, PEKKA RÄSÄNEN ${ }^{3}$ \\ ${ }^{1}$ Department of Pedagogy, University of Prishtina "Hasan Prishtina", Faculty of \\ Education, Pristina, Kosovo, contact: linda.salihu@uni-pr.edu, \\ ${ }^{2}$ Department of Education, Special Education, University of Jyväskylä, Finland, contact: mikko.t.aro@jyu.fi, \\ ${ }^{3}$ Niilo Mäki Institute, Finland, contact: pekka.rasanen@nmi.fi
}

Received: 31.03.2017.

Original scientific paper

Accepted: 20.11.2017.

UDK: $373.32: 51$

\begin{abstract}
The present study was designed to examine the effects of feedback conditions on learning and motivation of children identified with mathematical learning difficulties (MLDs). The performance of 76 fifth-grade children on computational math skills and related task motivation was assessed. The groups of children were randomly assigned to one of two treatment conditions: immediate corrective feedback or delayed conventional feedback on two occasions. Results showed that children performed significantly better when they were provided with the immediate corrective feedback than when they were provided with the delayed conventional feedback. The findings suggest that provision of the immediate corrective feedback also enhanced task motivation in children. In contrast, provision of the delayed conventional feedback had a negative impact on children's task motivation and also on their performance in math. Moreover, the results indicated that in the long term, children's subgroup (MLDs) and their previous math skills were powerful predictors of subsequent performance on a limited-time math task, whereas the change in task motivation did not contribute significantly to the same task.
\end{abstract}

Keywords: immediate corrective feedback, delayed conventional feedback, mathematical learning difficulties, mathematical performance, task motivation

\section{INTRODUCTION}

Several studies have shown the role of feedback to be critical for the learning process by drawing a general conclusion that some feedback is better than no feedback (for a review see Wiliam, 2011; Muijs et al., 2014; Shute, 2008; Hattie \& Timperley, 2007; Mory, 2004; Kluger \& DeNisi, 1996; Butler \& Winne, 1995; Bangert-Drowns, et al., 1991; Kulik \& Kulik, 1988; Fuchs \& Fuchs, 1986). However, this conclusion is not definitive and universal. Despite years of research, there is still disagreement related to feedback delivery options. In fact, research has produced controversial and non-consistent findings on feedback presentation and as Dempsey and associates (Dempsey et al., 1993) pointed out for example, the controversy over immediate versus delayed feedback becomes far more complex and consequently less settled than once thought.
The most popular theoretical explanation for the delay-retention effect was proposed by Kulhavy and Anderson (1972) who defined it as the interference-perseveration hypothesis. Interferenceperseveration assumes that initial error responses perseverate to the feedback stage, and tend to proactively interfere with the acquisition of the correct answer when the learner sees feedback immediately after responding. Thus, according to the authors, when feedback is delayed, initial errors are less well remembered, and the likelihood of substituting the correct response increases because errors are less interfering (Kulhavy \& Wager, 1993). On the other hand, the adequacy of the interference-perseveration hypothesis as an explanation for feedback effects in most actual classrooms was put into question from the findings of a number of meta-analyses (Hattie \& Timperley, 2007; Shute, 2008; Mason \& Bruning, 2001; Kulik \& Kulik, 
1988). The findings suggest that delaying feedback for struggling learners may prove to be frustrating and detrimental to their knowledge and skill acquisition, because these learners do not yet possess a solid base of knowledge and skills to enable successful task completion on their own, so they need assistance to confirm and verify their solutions during performance, not after it. Hence, the conclusion that immediate feedback is more effective to better facilitate learning (Hattie \& Timperley, 2007; Shute, 2008; Mory, 2004) than delayed feedback in applied settings has led researchers to investigate further whether application of delayed feedback in practical learning situations is beneficial or not (e.g., Brosvic et al., 2006; Dihoff et al., 2005).

Over the past decade, researchers (Dihoff et al., 2005; Dihoff et al., 2003; Epstein et al., 2003) have developed and applied an assessment tool known as the Immediate Feedback Assessment Technique (IF-AT), through which individualised performance feedback is coupled with the opportunity to answer until correct. According to Dihoff and associates (2005), the provision of immediate feedback, the use of answer-until-correct, and the encouragement of active and independent learning are three cardinal principles of pedagogy that can be implemented in IF-AT. Several studies have reported the effectiveness of IF-AT by applying it across different populations, ranging from preschool children with developmental delays (e.g., Epstein et al., 2003) to university students in classroom examinations (e.g., Dihoff et al., 2003; Dihoff et al., 2004; DiBattista et al., 2009). In each of these studies, provision of immediate corrective feedback promoted acquisition, greater retention and greater correction of initially inaccurate strategies than when the same stimuli were completed in the absence of immediate feedback. A common feature and perhaps a common challenge of all the studies was the attempt to shape, strengthen and maintain behaviours in learners that ultimately reinforce regulation of their own learning.

With this in mind, over the years it has been argued that higher achievers are better monitors of their own performance in school subjects, particularly in mathematics, than lower achievers (Schunk, 1996). If this is the case, then lower achievers need assistance in developing the skills to provide internal feedback to themselves in order to self-regulate their own learning (Dempsey et al, 1993). Without a doubt, one of the mechanisms for reaching or not reaching this ultimate goal of learning is the kind of feedback that teachers use in mathematics instruction. It has been suggested that feedback that emphasises how a learner's level of achievement differs from others' sets up a comparative structure that causes the learner to focus on him- or herself and on his or her own ability, and thus may reduce the interest in task learning (Dweck, 2007; Boekaerts \& Niemivirta, 2000; Hoska, 1993; Butler \& Nisan, 1986; Butler, 1987). Conversely, teachers who provide feedback that actively involves learners in exploratory and discovery learning cause them to draw and direct attention back to the task demands and increase their interest in investing a higher level of effort (Keith et al., 2010). Along this line, several studies suggest that learners who are given the chance to improve in mathematics through active feedback will have a positive perception of ability and will retain a high level of motivation (Narciss \& Huth, 2006; Hargreaves, 2013; Schunk, 1996; Butler, 1987; Butler \& Nisan, 1986). As Hoska (1993) noted earlier, a clear understanding of how learners respond to tasks can be gained only by understanding the dynamics of the learners' perspectives that motivate them to act in a certain manner (Hargreaves, 2013; Pekrun et al., 2002). It appears that one of the main functions of feedback during the learning process is not only to inform but also to motivate the learners to increase their efforts to self-adjust effectively to the learning task. Clearly, the motivational role of feedback is crucial for all learners, but for those learners who experience difficulties in learning and encounter repeated academic failure, this role is of especially critical importance.

Although the motivational function of feedback has been theoretically acknowledged by researchers (Hoska, 1993; Kulhavy \& Wager, 1993), this role is largely ignored in research practice (Corbalan et al., 2009; Vollmeyer \& Rheinberg, 2005). For instance, only one study to our knowledge (Narciss \& Huth, 2006) has taken this element into consideration and demonstrated that feedback simultaneously functions as an inform- 
er (cognitive component), reinforcer (behavioural component) and motivator (affective component) in mathematics learning. The tendency to deemphasise and--perhaps even worse--to artificially detach the motivational function from feedback is particularly disturbing when it is well-known that motivation is a powerful driving force for student learning and for approaching the task in a particular way (Pekrun et al., 2002; Pintrich, 2003, 1999; Keith et al., 2010; Hirvonen et al, 2012; Järvela et al., 2013). For this reason, it would be counterintuitive and counterproductive to investigate the informational function and motivational function of feedback separately.

The aim of the present study, therefore, was to broaden, as well as to deepen, the research focus on the effects of feedback. The purpose was to investigate simultaneously feedback effects on learning and motivation of children with mathematical learning difficulties (MLDs) by making comparisons between two conditions: immediate corrective feedback and delayed conventional feedback. The focus of interest was to examine how feedback conditions affect learning and motivation in computational math skills of children with MLDs.

On the basis of prior feedback studies, we predicted that immediate corrective feedback would be more beneficial for mathematical performance than delayed conventional feedback, because it encourages trial and error correction in understanding, thus maximising learning from task feedback without a direct intervention (Kluger \& DeNisi, 1993). Moreover, it would actively involve children in exploration and discovery of correct answers, which in turn would make them continually responsible for investing increasing amounts of effort, as well as monitoring and regulating their own learning (Butler \& Winne, 1995). Research also suggests that feedback should follow a response as closely in time as possible in order to be most effective (e.g., Mory, 2004; Brosvic et al., 2006; Dihoff et al., 2005; Epstein et al., 2003; DiBattista et al., 2009; Fuchs et al., 1991). In this way, immediate feedback should help fix errors in real time prior to being encoded into memory (Mason \& Bruning, 2001; Wager \& Mory, 1993), producing greater immediate gains and more efficient learning (Mason \& Bruning, 2001; Shute, 2008).
We also predicted that immediate corrective feedback should have more positive effect than delayed conventional feedback on mathematical task motivation, because it provides useful cues to draw and direct attention back to the task and resolve the gap between the current level of performance and the desired level of performance (Butler, 1987; Kluger \& DeNisi, 1996; Shute, 2008). Thus resolving this gap would increase the interest and motivate children to invest a higher level of effort and persist in seeking a correct answer (Hoska, 1993; Pintrich, 2003; Shute, 2008; Järvela et al., 2013).

Another issue of interest was to find out whether task motivation contributes to children's subsequent mathematical performance. It was assumed that along with initial math skills, intrinsic motivation and interest towards mathematics should be associated with high performance in mathematics (Aunola et al., 2006). Moreover, findings from several studies (Jordan et al., 2003; Geary et al., 2007; Geary et al., 2012) suggested that the role of children's subgroup in the development of math skills may also be a factor. Thus children's subgroup was also taken into consideration in order to thoroughly understand its contribution to subsequent performance in math skills.

\section{METHOD}

\section{Participants}

A total of 85 fifth-grade children $(M=139$ months, $S D=5.5$ months) with MLDs participated in the present study. Of these, 48 were boys and 37 were girls. Participants were identified and drawn from a larger sample $(N=237)$ on the basis of poor performance on the RMAT mathematics achievement (Räsänen, 2004; Räsänen \& Salihu, 2006). They came from eight classes of two urban $(n=$ $31)$, one suburban $(n=29)$ and one rural $(n=25)$ primary school, selected randomly in two municipalities of Kosovo with middle to low socio-economic status. Based on the RMAT test score, all children who scored below the 35 th percentile on national norms were included in the study. As suggested by prior research, there are two reasons for using this percentile cutoff. First, because it increases the possibility for picking up in the 
screening those children who have serious MLDs (Hanich et al., 2001; Jordan et al., 2003; Geary et al., 2000; Jordan \& Montani, 1997; Räsänen \& Ahonen, 1995), and second, math achievement based on RMAT score may mask children's specific deficits because the test contains different types of items (see Mazzocco, 2007; Mazzocco \& Myers, 2003; Gersten et al., 2005; Gersten et al., 2011, for a complete discussion). The subgroup of children comprised two categories of MLDs: children with low math achievement who scored above the 15th percentile on RMAT test and children with limited math ability who scored at or below the 15 th percentile on RMAT (Geary et al., 2007; Fuchs et al., 2008). All children attended general education classes and none of them was receiving special educational services. Informed consent letters were sent to the parents of all children before intervention began. The parents of all but one child gave permission for their children to participate in the study. During the study, nine children moved to other schools and another one, for personal reasons, discontinued further participation. In the end, 75 children whose parents gave informed consent were considered in further analyses. Prior to its initiation the study protocol was approved by the Ministry of Education, Science and Technology Committee.

\section{Design}

The effects of feedback conditions were investigated by a crossover experimental design with preand post-treatment measurements. Performance in arithmetic operations was examined two weeks prior to the intervention. After completion of the pretest, groups were randomly assigned to complete the first intervention period using one of the two feedback conditions (immediate or delayed), and they were switched to different conditions in the second intervention period. Participants provided with delayed feedback during the first intervention period received immediate feedback during the second intervention period and vice versa. The final testing was administered three months after each intervention period (summer break and winter break) with all participants completing the tasks and recording their responses on the answer forms in the absence of feedback.

\section{Measures}

Mathematics achievement. The children's mathematical achievement was assessed in groups of 12-15 participants using the RMAT Mathematical Achievement Test for Children 9-12 years Old (Räsänen, 2004; Räsänen \& Salihu, 2006). The original item selection for the RMAT was based on the idea of a restricted time for test completion to enable screening of many children in a short time (for more details see Räsänen, 2004). The test items were assessed first by conducting a pilot study with the Kosovo population. The Kosovo RMAT-test is a translation of the Finnish RMAT-test, and preliminary results showed that there was no need for major adaptation made to the items. This means that the original character of the Finnish RMAT-test items were not lost in the translation process. In Kosovo the test was used as a screening tool in order to identify children with mathematical difficulties a year and a half before the other data were collected. It was administered at two measurement points during 10 minutes of a class. Since RMAT was developed as a one-dimensional test (Räsänen, 2004), there is only one total score to interpret. The RMAT test is a quick screening tool that mainly consists of basic math skills, such as multi-digit calculations (e.g., $6000-$ 627; $204 \cdot 12$ ), fractions and decimals (e.g., 3/10; 5 - 0.3), measurement (e.g., $91=\ldots \mathrm{dl}$ ), and algebra tasks (e.g., x : $20=8$ ). In the RMAT test, one point is given for each correct answer. Consequently, the total maximum score for the test is 56 points. The children were asked to solve as many problems as they could. The reliability and validity of the RMAT test has been shown to be sufficiently high in Finnish populations (Räsänen, 2004) and Swedish populations (Räsänen, Linnanmäki, Haapamäki, \& Skagersten, 2008), and it has proven to be suitable for measuring mathematical skills of Kosovar children. As reported by Räsänen (2004), the Cronbach alpha reliability was $.92-.95$ at ages 9-12; the correlation with the WRAT-R (Jastak \& Wilkinson, 1984) was .547- .659. The Cronbach alpha coefficient on the Kosovo sample was .916. The RMAT test was used two more times with the group of children identified as having MLDs with an interval of six months between the second and third assessments. The Cronbach alpha reliabilities 
on this sample at two measurement points were .892 and .912 .

Calculation skills. The Mathematics Performance Test on Calculations (MPT-C; Salihu, 2008) comprised 25 items with one- and two-digit number combinations (addition, subtraction, multiplication, and division operations) and with four response options presented horizontally. It was administered at three measurement points (pre-treatment, post-treatment 1, and post-treatment 2) in a group classroom situation. The structure of the test was the same at all three measurement points. Children had 20 minutes to provide answers. The score was the number of correct answers. The Cronbach alpha reliabilities on this sample at the three measurement points were .889 , .831 , and .866 .

Weekly computational math skills. The children's computational math skills were also assessed using a set of 10 , one-and two-digit computational practice tasks (e.g., $8+25 ; 67-31 ; 18 \times 50$ ). These tasks were presented on an A1 sheet as a set of addition tasks (e.g., $27+69$; first week), subtraction tasks (e.g., $54-37$; second week), multiplication tasks (e.g., $57 \times 15$; third week), division tasks (e.g., 63 : 9; fourth week), and combinations of these tasks (e.g., $37+21: 7$; fifth week). Test items were selected and drawn mainly from primary school math textbooks or were prepared by the first author of this paper. The tasks were presented daily to children along with four proposed answers (i.e., $49-24$; $\mathrm{A}=53, \mathrm{~B}=35, \mathrm{C}=52$ or $\mathrm{D}$ $=25$ ) displayed horizontally on one page. Children recorded their answers on either the IF-AT form or on the answer sheet.

Task motivation. Children's task motivation was measured four times in an interview using the Task-value Scale for Children (TVS-C; Nurmi \& Aunola, 1999). The scale consisted of nine items measuring children's task motivation in reading, writing and mathematics. In the measurement procedure, first the experimenter asked the child questions such as 'How much do you like mathematics/ reading/writing?', 'How much do you like doing math/reading/writing-related tasks at school?', and 'How much do you like doing math/reading/writing-related tasks at home?' Then, a set of schematic pictures (with no points displayed beneath them) was shown to the child drawn to depict a five-point evaluative scale ranging from 5 (very much) to 1 (not at all) (Aunola et al., 2006). The child was then asked to point out the picture that most describes his or her liking of a particular subject (see Aunola et al., 2006). In this study only the children's task motivation related to mathematics was reported. The Cronbach alpha reliabilities on this sample at four measurement points ranged from .854 to .894 .

Nonverbal intelligence. Children's general IQ was assessed using Raven's Standard Progressive Matrices (SPM) (1976) test. The SPM measures nonverbal reasoning with 60 items divided into five sets (A, B, C, D, and E), each made up of 12 problems which become progressively more difficult. The test was administered individually only at the pretest step. The test administrator presented a series of patterns and the child selected the missing piece from 6 or 8 possible choices. The score is the number of correct responses. The test is considered to be an efficient instrument to measure cognitive ability of subjects from childhood until adulthood (Raven et al., 1998).

\section{Feedback conditions}

Immediate corrective feedback. The IF-AT (Dihoff et al., 2005; Brosvic et al., 2006) was used in a group classroom situation during the intervention period. The IF-AT form (see the sample form at epsteineducation.com) is a multiple-choice answer sheet with rows of rectangular answer spaces (i.e., A, B, C, D), corresponding to the alternatives for a number of multiple-choice items. For each item, the one box associated with the correct alternative has a small star in it, and the other boxes are blank. The form permits immediate delivery of corrective feedback on an item-by-item basis. Children in the immediate feedback condition scraped off an opaque, waxy coating covering an answer space on the IF-AT form to record their answers. If a star appeared the child received instant feedback that a correct response had been made; the absence of a star provided instant feedback that an incorrect response had been made. In case of an incorrect response, however, rather than simply exiting the task, the children were told to review the remaining response options, to continue to respond until discovering the correct answer and thus to exit each 
task with the correct answer (Dihoff et al., 2005). At the beginning of the intervention, the procedure was carefully explained to the children. After completion of the tasks on each practice test, children were told to score themselves by assigning 5 points for the first choice, 3 points for the second try, 2 points for the third try and 1 point for the fourth try.

Delayed conventional feedback. Delayed conventional feedback meant that information about the child's performance in the previous session was shown just before the next practice session, in order to allow the student to use the information on his or her subsequent performance. It is common that performance score is given to the school-age children after completing the task in a transparent manner either in verbal or written form (see McMillan \& Workman, 1998, for a complete discussion). In the first intervention period feedback contained the performance total score (knowledge of result) provided verbally, with no reference to individual test items. In the second intervention period, feedback contained the performance total score (knowledge of result) along with a reference to the correctness and incorrectness of individual test items provided in written form. In order to prevent and to avoid situations in which a child would compare his or her performance to that of peers, the delayed conventional feedback in the second period was provided in such a way that every child could focus on his/her own individual responses or performance on test items with no reference to what other children had done. The term 'delayed conventional feedback' was used in this study, because this kind of feedback typically is most widely used by school teachers in assessment of students' performance (McMillan \& Workman, 1998; Bangert-Drowns, et al., 1991; Kluger \& DeNisi, 1996). In short, the delayed conventional feedback resembled the instructional practices that teachers use in their daily work.

\section{Procedure}

A total of 41 participants completed 25 practice sessions using the immediate feedback provided by the IF-AT form (see the form at epsteineducation.com), and the remaining 34 completed their calculations with delayed conventional feedback provided by the experimenter who verbally (first intervention period) or in written form (second intervention period) announced performance score (knowledge of result) for each child in each subsequent session. In addition, 34 participants provided with delayed feedback during the first intervention period received immediate feedback during the second intervention, while 41 participants provided with immediate feedback during the first intervention period received delayed feedback during the second intervention period. Responses in the delayed conventional feedback condition were recorded by the participants on an answer form using a pencil to circle the correct answer, whereas responses in the immediate feedback condition were recorded on the IF-AT form. The intervention was conducted five times a week during or after the children's regularly scheduled class period. Only one session was completed per day on each of five consecutive weeks. Practice sessions lasted 10 minutes, during which participants completed the 10 -item math practice tasks in a regular group classroom situation. Group size varied between 7 and 15 participants $(M=10.9$, $S D=2.8$ ). Both groups were provided with the same practice tasks. At the beginning of each session, children were allowed to use a piece of paper for their calculations, a pencil and an eraser. Each session consisted of 10, one- and two-digit computational tasks (e.g., $8+25 ; 67-31 ; 18 \times 50$ ). The tasks were designed to become progressively more difficult across the practice tests. Children were instructed to use any strategy they wanted (i.e., counting on fingers, counting verbally, using tally marks, writing down an algorithm, retrieval and so forth) to get the correct answer. They were permitted to read or draw quietly if they completed the task before the end of the assigned time period. At posttest, upon the conclusion of the intervention period, each participant completed an interview assessing their task motivation in mathematics. All the tasks were presented by the first author.

\section{RESULTS}

Raw scores were used in the data analyses. All the analyses were performed at significance level .01. One-way analysis of variance (ANOVA) was performed first to check for the initial equivalence of the groups. The groups of children in the two 
conditions were equivalent in terms of the initial scores in pretreatment mathematical performance on MPT-Calculation, $F(1,73)=0.82, p=.776$; RMAT, $F(1,73)=0.19, p=.666$; and nonverbal reasoning, $F(1,73)=0.10, p=.751$.

Repeated-measures ANOVA with the assessment time point as a within-subjects factor was then applied on two dependent variables, MPTCalculation and RMAT tasks, using feedback condition (immediate vs. delayed) as a between-subjects factor (for the first intervention period and for the second intervention period). These analyses were performed because of carryover effects from the first intervention period. In Table 1, mean raw scores, standard deviations, and effect sizes are reported by condition. As presented in Table 1, after the intervention periods, the mean scores on MPT-Calculation and RMAT were substantially higher among children in the immediate feedback condition than in the delayed feedback condition, which indicates that when children were provided with the immediate corrective feedback they performed much better than when they were provided with the delayed conventional feedback. The analyses of children's mathematical performance showed significant interaction between feedback condition and assessment occasion for MPT-Calculation, $F(2,146)=55.67, p<.001, \eta^{2}$ $=.43$; and a significant main effect of assessment occasion among children, $F(2,146)=6.24, p=$ $.003, \eta^{2}=.08$ (see Figure 1). The same pattern was observed for RMAT with a significant interaction effect, $F(2,146)=23.51, p<.001, \eta^{2}=.24$; and a significant main effect, $F(2,146)=104.96$, $p<.001, \eta^{2}=.59$ (see Figure 2), suggesting the powerful impact of feedback type on children's performance over time. In order to determine the magnitude of the effects of the intervention, the gain scores from pre- to post-treatment 1 were computed first on each variable and then the difference between mean gain scores was divided by the pooled standard deviation (see Table 1 for effect sizes). For this purpose, univariate ANOVA was also performed on MPT-Calculation gain scores, $F(1,73)=17.20, p<.001, \eta^{2}=.19$; and on RMAT gain scores, $F(1,73)=6.15, p=.015, \eta^{2}=.08$ (see Johnson, 2010, for more details of crossover designs).
Table 1. Mathematical Performance at Measurement Times by Treatment Group

\begin{tabular}{|l|cc|cc|cc|}
\hline Variable & \multicolumn{2}{|c|}{$\begin{array}{c}\text { Pre- } \\
\text { treatment } \\
(\mathbf{n}=\mathbf{7 5})\end{array}$} & \multicolumn{2}{c|}{$\begin{array}{c}\text { Post- } \\
\text { treatment 1 } \\
(\mathbf{n}=\mathbf{7 5})\end{array}$} & \multicolumn{2}{c|}{$\begin{array}{c}\text { Post- } \\
\text { treatment 2 } \\
(\mathbf{n}=\mathbf{7 5})\end{array}$} \\
\hline MPT-C & $\mathrm{M}$ & $\mathrm{SD}$ & $\mathrm{M}$ & $\mathrm{SD}$ & $\mathrm{M}$ & $\mathrm{SD}$ \\
\hline Group 1 & 14.90 & 5.21 & 18.07 & 3.79 & 12.83 & 5.18 \\
\hline Group 2 & 14.50 & 6.97 & 14.29 & 5.37 & 17.85 & 4.78 \\
\hline Cohen's d & \multicolumn{7}{|c|}{0.83} \\
\hline RMAT & \multicolumn{7}{|c|}{} \\
\hline Group 1 & 16.29 & 5.31 & 24.98 & 5.91 & 21.51 & 8.46 \\
\hline Group 2 & 15.71 & 6.43 & 21.47 & 7.97 & 26.15 & 7.20 \\
\hline Cohen's d & \multicolumn{7}{|c|}{0.57} \\
\hline
\end{tabular}

Note. MPT-C = math performance test on calculations, RMAT $=$ math achievement test, $1=$ first intervention period, 2 = second intervention period.

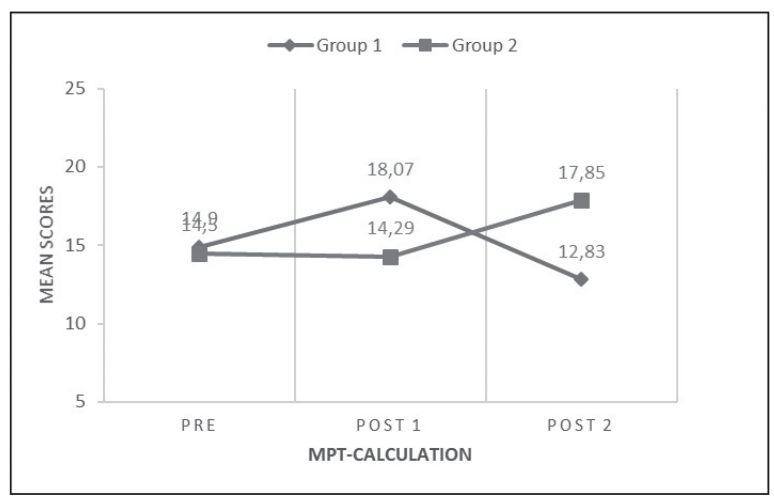

Figure 1. Performance in MPT-Calculation by Group Exposed to Two Feedback Conditions at Different Assessment Times

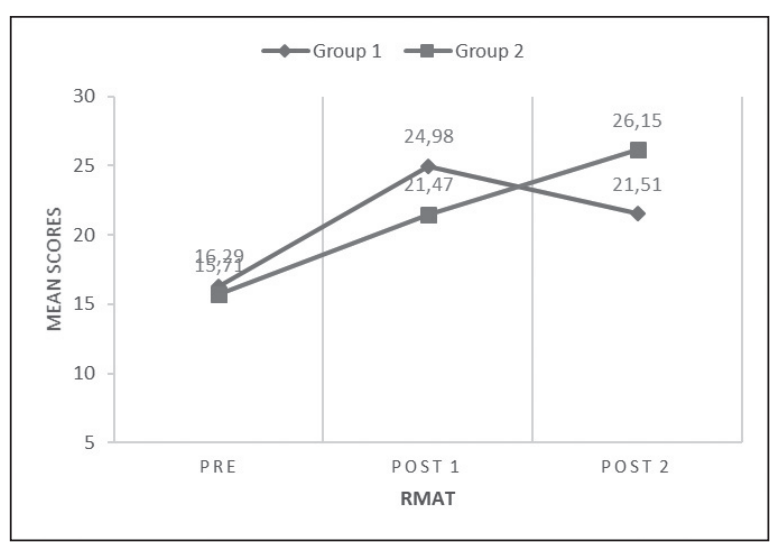

Figure 2. Performance in RMAT by Group Exposed to Two Feedback Conditions at Different Assessment Times 
Linda Salihu, Mikko Aro, Pekka Räsänen: Dynamic Potential of Feedback in Self-Regulated Learning and Motivation of Children With...

To examine children's motivation on a mathematics task, repeated-measures ANOVA was applied to math-related task motivation, with the assessment time as a within-subjects factor and feedback condition (immediate vs. delayed) as a between-subjects factor. Analysis revealed that at the beginning, groups differed significantly in the initial level of math task motivation, $F(1,73)$ $=20.98, p<.001$. After the intervention periods, math-related task motivation among children in the immediate feedback condition was substantially higher than their task motivation in the delayed feedback condition. The results showed significant interaction between feedback condition and assessment occasions for math task motivation, $F(3,204)=64.68, p<.001, \eta^{2}=.49$, but not a significant main effect, $F(3,204)=2.77, p>$ $.04, \eta^{2}=.04$. In addition, the contrast in math task motivation from pre- to post-test 1 was computed first to create a variable called change in math motivation. The results from the univariate ANOVA showed that the difference between the groups was highly significant $F(1,68)=171.87$, $p<.001, \eta^{2}=.72$ (see Johnson, 2010, for more details of crossover designs). The mean responses for all of the total task motivations were broken down by feedback condition and presented in Table 2 and Figure 3.

Table 2. Mean Responses at Measurement Times Assessing Mathematics Task Motivation by Treatment Groups

\begin{tabular}{|c|c|c|c|c|}
\hline Variable & $\begin{array}{c}\text { Pre-test } 1 \\
(n=75)\end{array}$ & $\begin{array}{c}\text { Post-test } 1 \\
(\mathrm{n}=75)\end{array}$ & $\begin{array}{c}\text { Pre-test } 2 \\
(n=75)\end{array}$ & $\begin{array}{c}\text { Post-test } 2 \\
(\mathrm{n}=75)\end{array}$ \\
\hline $\begin{array}{l}\text { Math- } \\
\text { related task } \\
\text { motivation }\end{array}$ & $\mathrm{M} \quad \mathrm{SD}$ & $\mathrm{M} \quad \mathrm{SD}$ & $\mathrm{M} \quad \mathrm{SD}$ & $\mathrm{M} \quad \mathrm{SD}$ \\
\hline Group 1 & $9.85 \quad 1.91$ & $\begin{array}{lll}12.31 & 1.59 \\
\end{array}$ & $10.68 \quad 2.20$ & $8.85 \quad 2.05$ \\
\hline Group 2 & 12.322 .23 & $9.13 \quad 1.61$ & 11.442 .09 & $\begin{array}{ll}12.03 & 1.97\end{array}$ \\
\hline
\end{tabular}

Note. $1=$ first intervention period, $2=$ second intervention period.

Another aspect of this study was to investigate the reciprocal relationship between children's task motivation in mathematics and their mathematical performance (MPT-Calculation and RMAT). Correlations between the sum variables in Table 3 showed that math task motivation was positively

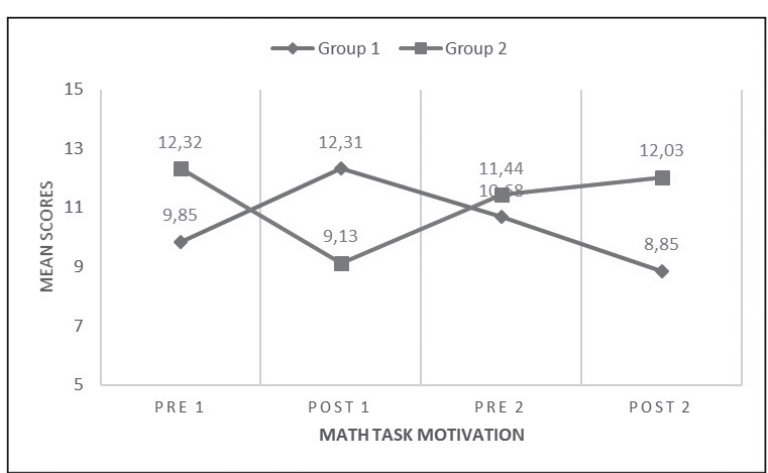

Figure 3. Mathematics Task Motivation by Group Exposed to Two Feedback Conditions at Different Assessment Times

associated with posttreatment mathematical performance but not with pretreatment math performance. The high positive correlations between the initial and subsequent math skills also indicated clear consistency in mathematical performance during the follow-up. The findings also revealed that the children's subgroup and their nonverbal intelligence correlated significantly with mathematical performance over time.

Because the analyses showed that treatment effects were significant on children's math task motivation, a change contrast from pre- to post-test 2 was included in the prediction model. Multiple regression analyses were performed between mathematical performance (MPT-Calculation and RMAT) at follow-up as the dependent variable and change in math task motivation as independent variable to determine the extent to which mathematical performance is related to change in math task motivation and to subgroup, as well as to determine the strength of relationships between these variables. The initial math skills tests (MPT-C and RMAT) at pretest were also entered as predictor variables in the regression equation. Table 4 displays statistics from these analyses. As it is shown, $R$ for regression was significantly different from zero for the MPT-Calculation, $F(3,71)$ $=41.36, p<.001, R^{2}=.64$; and for RMAT, $F(3$, $71)=17.02, p<.001, R^{2}=.42$. This indicates that altogether, about $62 \%$ and $39 \%$, respectively, of the variability in performance on MPT-Calculation and RMAT at follow-up was predicted by changes in children's math task motivation, subgroup, and the initial level of their math skills. In addition, the 
Table 3. Correlations between Mathematical Performance and Children's Task Motivation, Nonverbal Reasoning, and Their Subgroup $(n=75)$

\begin{tabular}{|c|c|c|c|c|c|c|c|c|c|c|c|c|}
\hline Variable & 1 & 2 & 3 & 4 & 5 & 6 & 7 & 8 & 9 & 10 & 11 & 12 \\
\hline \multicolumn{13}{|l|}{ 1. MPT-C initial test } \\
\hline 2. MPT-C 1 & $.768 * *$ & & & & & & & & & & & \\
\hline 3. MPT-C 2 & $.675^{* *}$ & $.431 * *$ & & & & & & & & & & \\
\hline 4. RMAT initial test & $.702 * *$ & $.653 * *$ & $.489 * *$ & & & & & & & & & \\
\hline 5. RMAT 1 & $.818^{* *}$ & $.831 * *$ & $.576^{* * *}$ & $.686^{* *}$ & & & & & & & & \\
\hline 6. RMAT 2 & $.742 * *$ & $.576^{* * *}$ & $.850 * *$ & $.587 * *$ & $.730 * *$ & - & & & & & & \\
\hline 7. Math-task motivation - Pre 1 & .109 & -.075 & .230 & .158 & .018 & .253 & - & & & & & \\
\hline 8. Math-task motivation -Post 1 & .128 & $.317 * *$ & -.281 & .130 & .271 & -.118 & -.039 & & & & & \\
\hline 9.Math-task motivation - Pre 2 & .231 & .230 & .032 & .200 & .283 & .120 & .242 & $.514 * *$ & & & & \\
\hline 10.Math-task motivation -Post 2 & .114 & -.095 & $.448 * *$ & .173 & .003 & $.408 * *$ & $.465 * *$ & -.273 & .204 & & & \\
\hline 11. RPM & $.355 * *$ & .263 & .286 & $.350 * *$ & $.401 * *$ & $.348 * *$ & .062 & .220 & .233 & .027 & & \\
\hline 12. Subgroup (MLDs) & $.561 * *$ & $.574 * *$ & $.480 * *$ & $.789 * *$ & $.645 * *$ & $.506 * *$ & -.085 & .028 & .068 & -.003 & $.349 * *$ & \\
\hline
\end{tabular}

Note. MPT-C = math performance test on calculations, RMAT = math achievement test, RPM = Raven's Progressive Matrices, MLDs $=$ mathematical learning difficulties. ${ }^{* *} \mathrm{p}<0.01$.

Table 4. Multiple Regression of Children's Change in Math Motivation, Subgroup, and Initial Math Skills

\begin{tabular}{|c|c|c|c|c|c|c|c|c|c|c|c|c|}
\hline \multicolumn{13}{|c|}{ Performance at follow-up } \\
\hline & \multicolumn{6}{|c|}{ MPT-Calculation } & \multicolumn{6}{|c|}{ RMAT } \\
\hline Predictor & $B$ & $S E$ & $\beta$ & $s r(i)^{2}$ & $t$ & $p$ & $B$ & $S E$ & $\beta$ & $s r(i)^{2}$ & $t$ & $p$ \\
\hline Change in motivation & .66 & .21 & .35 & .12 & 3.23 & .002 & .70 & .31 & .25 & .06 & 2.26 & .027 \\
\hline Subgroup (MLDs) & 7.30 & 1.36 & .50 & .25 & 5.35 & .001 & 11.20 & 2.07 & .52 & .27 & 5.41 & .000 \\
\hline Initial math skills & .57 & .08 & .62 & .26 & 7.15 & .001 & .66 & .21 & .47 & .08 & 3.18 & .002 \\
\hline \multirow[t]{2}{*}{ Constant } & 5.38 & 1.12 & & & 4.81 & .001 & 10.87 & 2.18 & & & 4.98 & .000 \\
\hline & \multicolumn{6}{|c|}{$\begin{array}{c}\mathrm{R}^{2}=.64 \\
\text { djusted } \mathrm{R}^{2}=.62 \\
\mathrm{R}=.80^{* *}\end{array}$} & \multicolumn{6}{|c|}{$\begin{array}{c}\mathrm{R}^{2}=.42 \\
\text { Adjusted } \mathrm{R}^{2}=.39 \\
\mathrm{R}=.65^{* *}\end{array}$} \\
\hline
\end{tabular}

Note. $\mathrm{MPT}=$ math performance test, RMAT $=$ math achievement test, MLDs $=$ mathematical learning difficulties. $* * \mathrm{p}<0.01$.

squared semipartial correlation coefficients showed that the three predictors accounted for unique variance in MPT-Calculation (12\%, 25\%, and 26\%) and RMAT $(6 \%, 27 \%$, and $8 \%)$, suggesting the determinant role of subgroup, changes in math task motivation, as well as initial math skills. It should be noted, however, that the contribution of changes in math motivation on the limited-time RMAT test was not significant, in contrast to the significant contribution from children's previous math skills and subgroup.

\section{DISCUSSION}

The present study investigated the effects of feedback on self-regulated learning and motivation of children with MLDs by making comparisons between two conditions: immediate corrective feedback and delayed conventional feedback. The results of the study demonstrated that providing immediate corrective feedback to children with MLDs promoted learning of computational skills, while the use of delayed conventional feedback in most of the cases prevented it. Furthermore, the results show that feedback was operating differently in two opposite directions. It was confirmed that while immediate corrective feedback rapidly improved children's computational math skills, delayed conventional feedback drastically impeded improvement in the two tasks of Calculation and RMAT. It should be noted that the latter finding was unexpected.

Overall, the results showed that immediate corrective feedback through an answer-until-correct format led to significantly higher learning gains by having a noticeable impact on children's math skills 
performance. The performance of the two groups of children was markedly distinct due to critical differences in the extent to which children mindfully processed information in the two feedback conditions. When children had to discover the correct answer in immediate corrective feedback, they were active seekers of knowledge and skills. When children received verification feedback containing information on the attained score (number of correct and incorrect responses), they lagged far behind in math skills improvement. Instead of useful information relevant to self-assessment and proactive self-engagement with task learning, the scores provided information about proficiency relative to others (Butler \& Nisan, 1986) and therefore such feedback may not have much utility for converting errors into new learning. Our results confirm the hypothesis that immediate corrective feedback would be significantly beneficial to children's self-regulation in learning of computational math skills.

There are a number of reasons for this improvement. First, children who received immediate corrective feedback had the opportunity to explore carefully the cues and underlying meanings relevant to the task involved (Dempsey et al., 1993), which enabled them to correct gaps or flaws in their knowledge. In other words, the cues that triggered actions in the form of cognitive strategies guided children's cognitive processing to make repairs in comprehension and positively influenced construction and reconstruction of their knowledge (comprehension) and acquisition of skills (Butler \& Winne, 1995). Second, it is evident that this was a salient reflective process since the information provided in immediate corrective feedback, which was then cognitively processed by children during self-regulation, was available for inspection in working memory. Immediate corrective feedback cued deeper processing of computational math skills and thus enhanced children's memory for that information on repeated similar tasks by allowing correct responses to be encoded into memory. Consistent with this finding, researchers (Konrad et al., 2007; Mason \& Bruning, 2001; Wager \& Mory, 1993) concluded that feedback that drives cognitive processing may offer an additional advantage by facilitating students' subsequent maintenance and transfer of those skills to similar tasks.
In addition, it is worthwhile to emphasise that another source of immediate as well as delayed feedback during the intervention was the internal one that children self-generated by monitoring their rate of progress. Monitoring or self-observation as a cognitive process guided the children's further actions through bridging past performance to the next phase of engaging with a task. As Butler and Winne (1995) noted, it is at these bridging points that self-regulation can serve learning and that feedback should be most useful. However, whether or not a child regulates learning depends to a great extent on his or her self-generated internal feedback triggered by external feedback (immediate or delayed), which in turn may play an essential and determinant role for decision-making in terms of approaching the task in a certain manner. The results show that children's engagement in mental activities aimed at processing the input provided in immediate corrective feedback and preparing an appropriate response, triggered monitoring that generated internal feedback (metacognition) in the form of constructing the reasoning for their responses during completion of a computational math task (for example, determining why and/ or how the chosen response was correct or incorrect). This kind of reasoning has been shown to be uniquely effective for facilitating learning gains (Desoete \& Veenman, 2006). Conversely, the knowledge of a score with or without correct and incorrect response implied children's ineffective monitoring of their performance, since it did not provide useful information to them on how to go about task completion and learning. Thus instead of accomplishing the learning task, children in the delayed feedback condition may have decided to disengage from it by escaping the task prematurely mentally or physically (Kluger \& DeNisi, 1996), rather than completing it. In such a condition, the task may have turned into nothing more than a guessing activity. Accordingly, the results show that the information provided in delayed conventional feedback was not helpful since it was not used by children to identify errors, actively seek the correct response, and correct their misconceptions on their own. As a result, that information was largely ignored by children, causing a decrease in their cognitive processing and comprehension of arithmetic operations. Consistent with this finding, 
Banger-Drowns and associates (1991) concluded that active feedback was reliably more helpful than passive outcome feedback that simply informed the learner whether a response was correct or incorrect.

The findings of the present study suggest that the motivational element at work in both feedback conditions should not be ignored; rather it deserves very close and special attention (Brown et al., 2012). It was confirmed that while immediate corrective feedback enhances children's task motivation in mathematics, delayed conventional feedback substantially suppresses it. Adverse reactions of children in delayed feedback conditions were observed particularly in those tasks that were continually practiced such as Calculation tasks. The current results parallel findings from previous investigations that emphasised that feedback may activate both positive and negative motivational effects (Hirvonen, et al., 2012; Hargreaves, 2013; Shute, 2008; Mory, 2004; Pekrun et al., 2002; Kluger \& DeNisi, 1996). An in-depth explanation for clarifying the latter feedback effect was given by Hoska (1993), who noted that usually learners who do not expect to succeed and have a strong intention to avoid failure in performing the learning task may determine that the task warrants little or no effort, and thus they may substantially lower their effort levels in task completion. Under such conditions, even though the learner is able and may feel capable of successfully performing the task, he or she may have decided to expend only minimal effort. Furthermore, since the learner feels that the amount of effort he or she has decided to invest will not be sufficient to achieve success, he or she may decide to reduce effort levels even further, perhaps to the point of not trying or investing any effort at all. In accordance with this interpretation, children in the delayed feedback condition failed to complete the math task but at the same time may have felt that they succeeded in avoiding failure: since they did not try, they did not fail. In other words, children might have reacted to delayed conventional feedback by withdrawing defensively their effort for task completion and by setting up and strengthening continually defensive measures to protect their sense of self-worth.

In sum, the present study provides evidence that feedback can indeed be a double-edged sword
(Kluger \& DeNisi, 1996): depending on its type (immediate corrective feedback or delayed conventional feedback), it has the potential to trigger mental and emotional reactions that can generate the children's instant decision to complete or avoid the task. Delayed conventional feedback was shown to be inappropriate because it impedes the children's performance as their attention might be diverted away from the task towards concern over the possibility of repeated poor performance or failure, causing continuous decrease in their confidence and sense of self-worth. In such an emotional and mental state, children given delayed conventional feedback were obviously unable to take control and turn failures around. In contrast, children receiving immediate corrective feedback experienced continually increasing levels of competence, which might help them to maintain positive self-images. Consistent with this finding, previous study suggested that the amount of invested effort often increases when struggling learners receive feedback from self-observation that indicates above-average performance, since it gives them learning experiences that are positive and internally satisfying (Narciss \& Huth, 2006).

Most of the children who received immediate corrective feedback pursued learning and extended effort with increased willingness to continue working and developing skills. They applied maximum effort, remained on task and did not give up when they encountered difficulties. Moreover, the children responded to difficulties by investing increased amounts of effort in order to overcome them and thus succeeded at doing and accomplishing the task. Being granted the responsibility for self-assessing and for assigning certain points to themselves while completing the test items, children in the immediate feedback condition were not only kept motivated to persist in pursuing the correct answer, but they also felt empowered to take control and responsibility for their own proficiency. Apparently, this kind of positive motivation was feeding children's cognition, mobilising them to undertake actions toward task completion (see Pintrich, 1999, 2003; Zimmerman \& Schunk, 2008, for a more complete discussion). It seems that these self-regulatory efforts (cognitive and affective) helped children to compensate their shortcomings in math task performance and learning. 
In addition, the linkage among self-regulated learning, motivation and feedback type (immediate and delayed) has substantial implications for instructional practices as well as for their design. Our findings support the effectiveness and efficacy of immediate corrective feedback as a supplement to instructional practice on learning computational skills. The study makes the point that all children can learn to be in charge of their own learning, but to do so they need a tool to confirm and verify their solutions during performance, not after it. When we talk about children with learning difficulties, who are not seldom considered as 'difficult to teach', this becomes even more appealing, because they do not yet possess a solid base of knowledge and they have yet to master skills to pursue and proceed to task completion on their own without assistance (Mason \& Bruning, 2001; Newman, 2008), and thus they may require several tries before mastering the subject matter (Wiggins, 2004). Clearly, immediate corrective feedback appears to be an effective pedagogical mechanism for promoting learning of computational skills since it serves as a kind of backup tool for the struggling learners. Consequently, it has been instrumental in helping children with MLDs to make positive changes become a reality, as most of them are capable of demonstrating self-instruction, self-assessment and self-monitoring (Hoska, 1993; Garret et al., 2006; Fuchs et al., 2003) without prompting from the teacher. Furthermore, the children in the immediate feedback condition became proactive in terms of taking the responsibility and control for the learning process, rather than reactive, which is more attributed to the children in the delayed feedback condition. This is because by giving children the correct answer before they proceed to the next test item, immediate corrective feedback can increase their confidence and feeling of self-worth. More specifically, children came to a confident knowledge of computational meaning through its constant verification and confirmation. In contrast, when children receiving delayed conventional feedback do not get instant answers, which they are unable to know beforehand, their confidence as well as their sense of self-worth can decrease (Igrić et al., 2012; Schwab et al., 2013).
Another factor to consider is that immediate corrective feedback enables individualised instruction with engagement of all children in the learning process, regardless of the class size, in terms of accepting diversity and embracing inclusion in regular classroom instruction. In this way, such feedback ensures a sound and sensible application of special education in the regular classroom since each individual child can proceed at his or her own pace on an individual basis in accordance with his or her learning needs. In this vein, immediate corrective feedback in our study helped children to learn to depend on themselves and to be willing to explore and push hard the limits for better results, which in turn created higher-quality learning outcomes and thereby may have boosted their sense of competence and well-being (Boekaerts, 1993; Boekaerts \& Corno, 2005; Tuominen-Soini et al., 2008; Andresen, 2014). In other words, immediate corrective feedback works because it is not about the child's flaws and it therefore spares his or her self-worth. It provides information during performance and serves as a kind of reinforcer for independent task solving and learning (Dihoff et al., 2005).

\section{Limitations}

Although the results are notable, there are at least three limitations that should be taken into account in any attempts to generalise the findings and replicate further the present study. First, the fact that there was deterioration in performance and motivation of children provided with delayed conventional feedback was very discouraging. Nevertheless, in order to find out the truth about how feedback conditions function, we had to use dozens of children to save thousands of others from struggling and suffering in math learning. Second, it is noteworthy that the only aspect of the scale measuring task motivation was the interest task value (Aunola et al., 2006). This means that the scale we used did not include other aspects of task value, such as attainment value and utility value. Undeniably, by considering more aspects of task value, such as those mentioned above, we would be able to get a more complete and comprehensive picture of children's task motivation and its contribution to self-regulation in mathematics learning. 
Finally, if the study had had a third group as a "real" control group, we would be able to know more about the advantages and disadvantages of treatment conditions by comparing to no intervention (Kluger \& DeNisi, 1996).

\section{CONCLUSION AND FUTURE DIRECTIONS}

Overall, the results showed, first, that changes in math task motivation at posttest predicted children's mathematical performance at follow-up. This suggests that the changes that happened due to feedback conditions (immediate and delayed) strongly influenced children's cognitive engagement in mathematical performance, particularly on the Calculation task. This was not the case for the RMAT task. Moreover, our findings shed light on the role of subgroup as a potential source of children's performance on math skills. This suggests that the children's mathematical performance was determined by the subgroup's classification (MLDs) to which they belonged. Finally, it is also shown that previous mathematical skills of children predicted the level of mathematical performance at follow-up.

The findings of the present study give insight and understanding into a decades-old instructional concern by demonstrating that despite the amount and prolonged time devoted to mathematics instruction, practice in conjunction with delayed conventional feedback by itself does not improve children's performance, but can also cause decrements in performance (Shute, 2008; McMillan \& Workman, 1998; Kluger \& DeNisi, 1996). In fact, this kind of instructional practice that is frequently used for math learning provides fewer or no opportunities for children to discover task rules, such as patterns and relationships, and provides little encouragement to do so. As a result, it can turn into nothing more than a meaningless, boring, and frustrating activity for struggling learners with no relevance for them, and consequently with degrading educational outcomes. Thus, the findings of the study provide a sobering lesson for the necessity of pairing practice with appropriate and effective feedback, such as immediate corrective feedback, to help children self-direct their own actions toward the learning task and to make a distinctive difference in their progress.

Finally, behavioural indicators such as positive and negative emotions induced by feedback conditions (immediate and delayed) as the main characteristics of the motivational state represent a vital measure of children's well-being. From all indications we can conclude that delayed conventional feedback is really deteriorating and it is quite obvious that such feedback presents a potential threat to children with learning difficulties. It encourages not only the children's mindlessness but it triggers their impulsiveness, too. Delayed conventional feedback is perceived as a kind of criticism for not doing well, which will cause almost every learner to become defensive by protesting against it, because that kind of criticism stirs up negative emotions that undermine the learner's self-confidence. Indeed, dwelling persistently on distressing situations from the recent or distant academic past is considered to be one of the most destructive mental habits. It is closely linked to depression, and it can sap children's confidence, their ability to solve problems, and their sense of control over their learning and probably their own lives. Thus, teachers and other educators should take the importance of feedback very seriously into consideration, as it may have profound long-term effects as well as harmful consequences not only on children's learning, but also on their well-being. Researchers, educational policymakers, educationalists, psychologists, school counselors, social workers, principals, and parents should often remind themselves that along with learning, children's well-being should become teachers' and other educators' main concern as well as the top priority in their everyday work, and they must accept due responsibility for it. With this in mind, it is also important to acknowledge the powerful role that feedback plays in children's daily school life, and recognise that how children think, feel and perform is dictated to a great extent by the type of feedback they get from their teachers. Working with children with learning difficulties means that teachers should break the conformity and try to put themselves for a while in children's place and look at themselves from children's perspective. That would help them not only to genuinely under- 
stand what is really happening in children's inner world, but most importantly to be able to go further and believe honestly in the motto that "every child can learn" and work humanly to prove it. Toward this aim, future research is needed. We believe that the insights and thoughts from this study will be intriguing for further investigation and exploration of the power of feedback in relation to self-regulation and motivation in mathematics learning.

\section{AKNOWLEDGMENTS}

This study was supported by the Finnish Support to the Development of Education Sector in Kosovo (FSDEK II) Project and partly by the University of Prishtina "Hasan Prishtina". Special thanks are due to Dr. Cathal Butler for proofreading the manuscript.

We are deeply grateful to each and every child who participated in the study and made this work possible. 


\section{REFERENCES}

Andresen, S. (2014): Educational science and child well-being. In: Ben-Arieh, A., Casas, F., Frønes, I., Korbin, J. E. (Eds.), Handbook of Child Well-Being: Theories, Methods and Policies in Global Perspective 2. (pp. 249-278). New York: Springer Reference.

Aunola, K., Leskinen, E., Nurmi J.-E. (2006): Developmental dynamics between mathematical performance, task motivation, and teachers' goals during the transition to primary school. British Journal of Educational Psychology, $76,21-40$.

Bangert-Drowns, R. L., Kulik, C. C., Kulik, J. A., Morgan, M. T. (1991): The instructional effect of feedback in testlike events. Review of Educational Research, 61, 213-238.

Boekaerts, M., Corno, L. (2005): Self-regulation in the classroom: A perspective on assessment and intervention. Applied Psychology: An International Review, 54, 2, 199-231.

Boekaerts, M., Niemivirta, M. (2000): Self-regulated learning: Finding a balance between learning goals and egoprotective goals. In: Boekaerts, M., Pintrich, P. R., Zeidner, M. (Eds.), Handbook of Self-Regulation. (pp. $417-$ 450). San Diego: Academic.

Boekaerts, M. (1993): Being concerned with well-being and with learning. Educational Psychologist, 28, 2, 149-167.

Brosvic, G. M., Dihoff, R. E., Epstein, M. L., Cook, M. J. (2006): Feedback facilitates the acquisition and retention of numerical fact series by elementary school students with mathematics learning disabilities. The Psychological Record, 56, 35-54.

Brown, G. T. L., Harris, L. R., Harnett, J. (2012): Teacher beliefs about feedback within an assessment for learning environment: Endorsement of improved learning over student well- being. Teaching and Teacher Education, 28, 968-978.

Butler, D. L., Winne, P. H. (1995): Feedback and self-regulated learning: A theoretical synthesis. Review of Educational Research, 65, 3, 245-281.

Butler, R. (1987): Task-involving and ego-involving properties of evaluations: effects of different feedback conditions on motivational perceptions, interest and performance. Journal of Educational Psychology, 79, 4, 474-482.

Butler, R., Nisan, M. (1986): Effects of no feedback, task-related comments, and grades on intrinsic motivation and performance. Journal of Educational Psychology, 78, 3, 210-216.

Corbalan, G., Kester, L., van Merriënboer, J. J. G. (2009): Dynamic task selection: Effects of feedback and learner control on efficiency and motivation. Learning and Instruction, 19, 455-465.

Dempsey, J., Driscoll, M., Swindell, L. (1993): Text-based feedback. In: Dempsey J., Ales, G. (Eds.), Interactive Instruction and Feedback. (pp. 21-54). Englewood Cliffs: Educational Technology Publications.

Desoete, A., Veenman, M. (2006): Metacognition in mathematics: Critical issues on nature, theory, assessment and treatment. In: Desoete, A., Veenman, M. (Eds.), Metacognition in Mathematics Education. (pp. 1-10). Hauppauge $\&$ New York: Nova Science Publishers.

DiBattista, D., Gosse, L., Sinnige-Egger, J.-E., Candale, B., Sargeson, K. (2009): Grading scheme, test difficulty and the immediate feedback assessment technique. The Journal of Experimental Education, 77, 4, 311-336.

Dihoff, R. E., Brosvic, G. M., Epstein, M. L., Cook, M. J. (2005): Adjunctive role for immediate feedback in the acquisition and retention of mathematical fact series by elementary school students classified with mild mental retardation. The Psychological Record, 55, 39-66.

Dihoff, R. E., Brosvic, G. M., Epstein, M. L., Cook, M. J. (2004): Provision of feedback during preparation for academic testing: Learning is enhanced by immediate but not delayed feedback. The Psychological Record, 54, 207-231.

Dihoff, R. E., Brosvic, G. M., Epstein, M. L. (2003): The role of feedback during academic testing: The delay retention effect revisited. The Psychological Record, 53, 533-548. 
Dweck, C. S. (2007): Boosting achievement with messages that motivate. Education Canada, 47, 2, 6-10.

Epstein, M. L., Brosvic, G. M., Costner, K. L., Dihoff, R. E., Lazarus, A. D. (2003): Effectiveness of feedback during the testing of preschool, elementary school children, and adolescents with developmental delays. The Psychological Record, 53, 177-195.

Fuchs, L. S., Compton, D. L., Fuchs, D., Hollenbeck, K. N., Craddock, C. F., \& Hamlett, C. L.

(2008): Dynamic assessment of algebraic learning in predicting third graders' development of

mathematical problem solving. Journal of Educational Psychology, 100, 829-850.

Fuchs, L. S., Fuchs, D., Prentice, K., Burch, M., Hamlett, C. L., Owen, R., Schroeter, K. (2003): Enhancing thirdgrade students' mathematical problem solving with self-regulated learning strategies. Journal of Educational Psychology, 95, 306-315.

Fuchs, L. S., Fuchs, D., Hamlett, C. L., Whinnery, K. (1991): Effects of goal line feedback on level, slope, and stability of performance within curriculum-based measurement. Learning Disabilities Research and Practice, 6, 66-74.

Fuchs, L.S., Fuchs, D. (1986): Effects of systematic formative evaluation - A meta analysis. Exceptional Children, $53,3,199-208$.

Garret, A. J., Mazzocco, M. M. M., Baker, L. (2006): Development of metacognitive skills of prediction and evaluation in children with or without math disability. Learning Disabilities Research and Practice, 21, 77-88.

Geary, D. C., Hamson, C. O., Hoard, M. K. (2000): Numerical and arithmetical cognition: A longitudinal study of process and concept deficits in children with learning disability. Journal of Experimental Child Psychology, 77, 236-263.

Geary, D. C., Hoard, M. K., Byrd-Cravent, J., Nugent, L., Numtee, C. (2007): Cognitive mechanisms underlying achievement deficits in children with mathematical learning disability. Child Development, 78, 4, 1343-1359.

Geary, D. C., Hoard, M. K., Nugent, L., Bailey, D. H. (2012): Mathematical cognition deficits in children with learning disabilities and persistent low achievement: A five-year prospective study. Journal of Educational Psychology, 104, 206-223.

Gersten, R., Jordan, N. C., Flojo, J. R. (2005): Early identification and interventions for students with mathematical difficulties. Journal of Learning Disabilities, 38, 4, 293-304.

Gersten, R., Clarke, B. S., Haymond, K., Jordan, N. C. (2011): Screening for Mathematics Difficulties in K-3 Students. (2nd ed.). Portsmouth: RMC Research Corporation, Center on Instruction.

Hanich, L. B., Jordan, N. C., Kaplan, D., Dick, J. (2001): Performance across different areas of mathematical cognition in children with learning difficulties. Journal of Educational Psychology, 93, 3, 615-626.

Hargreaves, E. (2013): Inquiring into children's experiences of teacher feedback: Reconceptualising Assessment for Learning. Oxford Review of Education, 39, 1, 229-246.

Hattie, J., Timperley, H. (2007): The power of feedback. Review of Educational Research, 77, 81- 112.

Hirvonen, R., Tolvanen, A., Aunola, K., Nurmi, J.-E. (2012): The developmental dynamics of task-avoidant behavior and math performance in kindergarten and elementary school. Learning and Individual Differences, 22, 715-723.

Hoska, D. M. (1993): Motivating learners through CBI feedback: Developing a positive learner perspective. In: Dempsey, J., Ales, G. (Eds.), Interactive Instruction and Feedback. (pp. 105- 132). Englewood Cliffs: Educational Technology Publications.

Igrić, Lj., Jakab, A. W., Cvitković, D. (2012): Samoprocjena i procjena ponašanja učenika s

teškoćama u redovnoj osnovnoj školi [Assessment and self-assessment of behaviour of pupils with difficulties in a regular primary school]. Hrvatska Revija za Rehabilitacijska Istraživanja, 48, 1, 1-10.

Jastak, S., Wilkinson, G. S. (1984): The Wide Range Achievement Test - Revised. Wilmington: Jastak Associates. 
Järvela, S., Järvenoja, H., Näykki, P. (2013): Analyzing regulation of motivation as an individual social process: A situated approach. In: Volet, S., Vauras, M. (Eds.), Interpersonal Regulation of Learning and Motivation. (pp. 170-187). London: Routledge.

Johnson, D. E. (2010): Crossover experiments. Wiley Interdisciplinary Reviews: Computational

Statistics, 2, 5, 620-625.

Jordan, N. C., Hanich, L. B., Kaplan, D. (2003): A longitudinal study of mathematical competencies in children with specific mathematics difficulties versus children with co- morbid mathematics and reading difficulties. Child Development, 74, 834-850.

Jordan, N. C., Montani, T. O. (1997): Cognitive arithmetic and problem solving: A comparison of children with specific and general mathematics difficulties. Journal of Learning Disabilities, 30, 6, 624-634.

Keith, N., Richter, T., Naumann, J. (2010): Active/exploratory training promotes transfer even in learners with low motivation and cognitive ability. Applied Psychology: An International Review, 59, 1, 97-123.

Kluger, A. N., DeNisi, A. (1996): The effects of feedback interventions on performance: A historical review, a metaanalysis, and a preliminary feedback intervention theory. Psychological Bulletin, 119, 254-284.

Kluger, A. N., DeNisi, A. (1998): Feedback interventions: Toward the understanding of a double- edged sword. Current Directions in Psychological Science, 7, 3, 67-72.

Konrad, M., Fowler, C. H., Walker, A. R., Test, D. W., Wood, W. M. (2007): Effects of self- determination interventions on the academic skills of students with learning disabilities. Learning Disability Quarterly, 30, 89-113.

Kulhavy, R. W., Wager, W. (1993): Feedback in programmed instruction: Historical context and implications for practice. In: Dempsey, J., Ales, G. (Eds.), Interactive Instruction and Feedback. (pp. 3-20). Englewood Cliffs: Educational Technology Publications.

Kulhavy, R. W., Anderson, R. C. (1972): Delay-retention effect with multiple-choice tests. Journal of Educational Psychology, 63, 5, 505-512.

Kulik, J. A., Kulik, C. C. (1988): Timing of feedback and verbal learning. Review of Educational Research, 58, 1, 79-97.

Mason, B. J., Bruning, R. H. (2001): Providing feedback in computer-based instruction: What the research tell us. CLASS Research Report No. 9. Center for Instructional Innovation, University of Nebraska-Lincoln.

Mazzocco, M. M. M. (2007): Defining and differentiating mathematical learning disabilities and difficulties. In: Berch, D. B., Mazzocco, M. M. M. (Eds.), Why is Math So Hard for Some Children: The Nature and Origins of Mathematical Learning Difficulties and Disabilities. (pp. 29-47). Baltimore: Brookes Publishing.

Mazzocco, M. M. M., Myers, G. F. (2003): Complexities in identifying and defining mathematics learning disability in the primary school-age years. Annals of Dyslexia, 53, 218-253.

McMillan, J. H., Workman, D. J. (1998): Classroom Assessment and Grading Practices: A Review

of the Literature. (ERIC Document no. ED453263). Richmond: Metropolitan Educational Research Consortium (MERC).

Mory, E. H. (2004): Feedback research revisited. In: Jonassen, D. H. (Ed.), Handbook of Research

on Educational Communications and Technology. (pp. 745-783). Mahwah: Erlbaum.

Muijs, D., Kyriakides, L., van der Werf, G., Creemers, B., Timperley, H., Earl, L. (2014): State of the art - teacher effectiveness and professional learning. School Effectiveness and School Improvement, 25, 231-256.

Narciss, S., Huth, K. (2006): Fostering achievement and motivation with bug-related tutoring feedback in a computer based training for written subtraction. Learning and Instruction, 16, 310-322.

Newman, R. S. (2008): The motivational role of adaptive help seeking in self-regulated learning. In: Schunk, D. H., Zimmerman, B. J. (Eds.), Motivation and Self-Regulating Learning: Theory, Research and Applications. (pp. 315-337). New York: Erlbaum. 
Nurmi, J.-E., Aunola, K. (1999): Task-Value Scale for Children (TVSC). Unpublished test material. University of Jyväskylä.

Pekrun, R., Goetz, Th., Titz, W., Perry, R. P. (2002): Academic emotions in students' self- regulated learning and achievement: A program of quantitative and qualitative research. Educational Psychologist. 37, 91-105.

Pintrich, P. R. (2003): A motivational science perspective on the role of student motivation in learning and teaching contexts. Journal of Educational Psychology. 95, 667-686.

Pintrich, P. R. (1999): The role of motivation in promoting and sustaining self-regulated learning. International Journal of Educational Research. 31, 459-470.

Raven, J. C. (1976): Standard Progressive Matrices: Sets A, B, C, D \& E. Oxford: Oxford Psychologists Press.

Raven, J., Raven, J. C., Court, J. H. (1998): Manual for Standard Progressive Matrices: Including the Parallel and Plus Versions. San Antonio: Harcourt.

Räsänen, P. (2004): RMAT (laskutaidon testi 9-12 -vuotiaille: Kasikirja) [A mathematical achievement test for 9-12-year-olds: Manual]. Jyväskylä: Niilo Mäki Institute.

Räsänen, P., Salihu, L. (2006): RMAT - Testi i arritshmërisë në matematikë për moshën 9-12

vjeçare [A mathematical achievement test for 9-12-year-olds]. Jyväskylä: Niilo Mäki Institute.

Räsänen, P., Linnanmäki, K., Haapamäki, C., Skagersten, D. (2008): RMAT - Test av räknefärdighet hos evelver i åldern 9-12 år [A mathematical achievement test for ages 9-12 in Finnish-Swedish]. Jyväskylä: Niilo Mäki Institute.

Räsänen, P., Ahonen, T. (1995): Arithmetic disabilities with and without reading difficulties: A comparison of arithmetic errors. Developmental Neuropsychology, 11, 275-295.

Salihu, L. (2008): Testi i Performancës në Matematikë - Kalkulimet (TPM-K) [Mathematics Performance Test on Calculations, MPT-C]. Unpublished test material. University of Prishtina.

Schunk, D. H. (1996): Goal and self-evaluative influences during children's cognitive skill learning. American Educational Research Journal, 33, 359-382.

Schunk, D. H., Cox, P. D. (1986): Strategy training and attributional feedback with learning disabled students. Journal of Educational Psychology, 78, 201-209.

Schwab, S., Gebhardt, M., Gasteiger-Klicpera, B. (2013): Predictors of social inclusion of students

with and without SEN in integrated settings. Hrvatska Revija za Rehabilitacijska Istraživanja, 49, Supplement, 106-114.

Shute, V. J. (2008): Focus on formative feedback. Review of Educational Research, 78, 153-189.

Tuominen-Soini, H., Salmela-Aro, K., Niemivirta, M. (2008): Achievement goal orientations and subjective wellbeing: A person-centered analysis. Learning and Instruction, 18, 251-266.

Vollmeyer, R., Rheinberg, F. (2005): A surprising effect of feedback on learning. Learning and Instruction, 15, 589-602.

Wager, W. Mory, E. H. (1993): The role of questions in learning. In: Dempsey, J., Ales, G. (Eds.), Interactive Instruction and Feedback. (pp. 55-73). Englewood Cliffs: Educational Technology Publications.

Wiggins, G. (2004): Assessment as feedback. New Horizons for Learning, Baltimore: Johns Hopkins School of Education; Retrieved 20 February, 2009 from

http://education.jhu.edu/PD/newhorizons/strategies/topics/Assessment\%20Alternatives/wiggins.htm

Wiliam, D. (2011): What is assessment for learning? Studies in Educational Evaluation. 37, 3-14.

Winne, Ph. H., Hadwin, A. F. (2008): The weave of motivation and self-regulated learning. In: Schunk, D. H., Zimmerman, B. J. (Eds.), Motivation and Self-Regulated Learning: Theory, Research and Applications. (pp. 297-314). New York: Erlbaum. 
Zimmerman, B. J., Schunk, D. H. (2008): Motivation: An essential dimension of self-regulated learning. In: Schunk, D. H., Zimmerman, B. J. (Eds.), Motivation and Self-Regulated Learning: Theory, Research and Applications. (pp. 1-30). New York: Erlbaum.

\section{DINAMIČKI POTENCIJAL POVRATNIH INFORMACIJA U SAMOREGULIRANOM UČENJU I MOTIVACIJI DJECE S TEŠKOĆAMA U UČENJU MATEMATIKE}

Sažetak: Ovim istraživanjem želio se ispitati učinak vrste povratnih informacija (feedback-a) na učenje i motivaciju djece s teškoćama u učenju matematike. Procijenjena je izvedba 76-ero djece-polaznika petih razreda na zadacima računanja, kao $i$ njihova motivacija za rješavanje matematičkih zadataka, s obzirom na vrstu povratne informacije: trenutnu korektivnu povratnu informaciju te odgođenu konvencionalnu povratnu informaciju. Rezultati istraživanja pokazali su da su djeca imala značajno bolji rezultat kada im je bila pružena trenutna korektivna povratna informacija, nego kada im je pružena odgođena konvencionalna povratna informacija. Rezultati također ukazuju da pružanje trenutne povratne informacije povećava motivaciju učenika za rješavanje zadataka. S druge strane, pružanje odgođene povratne informacije imalo je negativan utjecaj na motivaciju, kao $i$ na izvedbu u rješavanju matematičkih zadataka. Rezultati također pokazuju da su prisutnost matematičkih teškoća i prethodna razina razvoja matematičkih vještina bili značajni prediktori kasnije uspješnosti u rješavanju vremenski ograničenih zadataka, što, međutim, nije bio slučaj s promjenama u motiviranosti učenika.

Ključne riječi: trenutna korektivna povratna informacija, odgođena konvencionalna povratna informacija, teškoće u učenju matematike, motivacija za učenje matematike 